\title{
Fritz Lang's Three Versions of Doctor Mabuse
}

The Complete Fritz Lang Mabuse Boxset

Eureka / Masters of Cinema / Region 2 DVD Box sets (3 films, 4 DVDs):

Dr Mabuse - Der Spieler (parts I \& II) (1922)

270 mins, 1.37:1 original aspect ratio

Includes optional English subtitles and the original German intertitles

Das Testament des Dr Mabuse (1933)

116 mins, $1.19: 1$ original aspect ratio

Includes optional English subtitles and the original German soundtrack

Die 1000 Augen des Dr Mabuse (1960)

99 mins, 1.66:1 original aspect ratio

Includes optional English subtitles and the original German soundtrack

All three films are accompanied with optional feature length audio commentary by film scholar David Kalat; in addition each DVD is supplemented by other extras such as essays and interviews from a range of contributors.

The name Fritz Lang is most readily associated with his silent 1927 epic Metropolis, a film that re-emerges from the shadows, meeting with almost guaranteed public anticipation of a 'newly restored' version. The most

The New Soundtrack 1.2 (2011): 181-189

DOI: $10.3366 /$ sound.2011.0019

(C) Edinburgh University Press

www.eupjournals.com/SOUND 
I. Each DVD case is accompanied by a booklet in which a number of film scholars provide essays and discussions on the significance of each Mabuse installment. recent release of a polished and extended Metropolis followed the surprise discovery of material hitherto thought lost, discovered in a film archive in Argentina. It was screened amidst great excitement at the Berlin Film festival in 2010 and released on DVD in November of the same year. Not wanting to distract from the richly deserved reputation of Metropolis as a classic film (nor from its astonishing mise-en-scene on a grand scale which plunged the production studio Ufa into financial crisis), it should be remembered that Fritz Lang directed more than forty films over his long career and his Dr Mabuse films represent another milestone worthy of attention. Happily, a new box set by the Eureka Masters of Cinema series now invites English speaking audiences to re-acquaint themselves with this significant part of Lang's creative output.

This latest DVD release is the product of a lengthy restoration project co-ordinating materials held in several key archives in Germany. Restoration work was completed in the early part of the new millennium, but with the addition of English language subtitles and other DVD extras, this triptych became available for the UK / US market only relatively recently (in 2009). Alongside its very informative print material, ${ }^{1}$ the three-piece box set incorporates both parts of the first Mabuse story, Dr Mabuse-Der Spieler (1922) as well as Lang's two subsequent installments of the story. Lang presented his first Mabuse story in two parts - the first with the subtitle Ein Bild der Zeit (A picture of the time) and the second part Ein Spiel von Menschen unserer Zeit (A play about people of our time). The two parts were premiered about one month apart in Berlin during the spring of 1922. Both subtitles illustrate Lang's desire to link the subject matter of his dramatic narrative to the socio-economic conditions of Germany at the time. The country's currency was in a downward spiral of hyperinflation, from which ruthless stock-market players sought to profiteer - at the expense of the working classes who were racked by rapidly declining living standards, as their wages went out of sync with the spiraling costs of rent and food.

It is unclear whether a score to the 1922 Mabuse films ever existed, but the DVD release is presented with music specially composed for this restored version by Aljoscha Zimmermann. Visually ambitious, its miseen-scene clearly rooted in the expressionism extant in many German films of the period, Dr Mabuse - Der Spieler has rightfully earned a cinematic reputation equal to Wiene's Das Cabinet des Dr Caligari (The Cabinet of Dr Caligari, Wiene, 1920) or Nosferatu-Eine Symphonie des Grauens (Nosferatu, a Symphony of Horror, Murnau, 1922).

With the introduction of sync sound in the late 1920s, new artistic potential invigorated the film making process. The first full length German sound film was Melodie des Herzens (Melody of the Heart), and was directed by Hanns Schwarz in 1929; its producer was Erich Pommer (who had also produced Lang's first Dr Mabuse films). The invention of sync sound within a standardised format of cinema exhibition enabled producers to exercise greater control of what audiences experienced with eyes and ears. Of course, it would be overly simplistic to hail the period as one of unstoppable audio-visual creativity. Many exponents of the early 
sound era lacked significant flair, and were creatively almost indifferent beyond the ambition of recording image and sound in sync.

Many film critics and theorists responded with scepticism to the new technology; Eisenstein and others warned against the perils of focusing on wordy dialogue scripts or facile song and dance routines. However, Lang's early sound films have grown to be appreciated by film fans as remarkably accomplished examples of the form.

Presented as part of the DVD box set then is the 1933 version of Das Testament des Dr Mabuse (The Testament of Dr Mabuse) - after M (1931), this was Lang's second film using new sound technology. Also included in the set is the 1960 film Die 1000 Augen des Dr Mabuse (The Thousand Eyes of Dr Mabuse). Lang's third encounter with the Mabuse story has never come close to rivalling the artistic credentials of his other two. In comparison to the visual expressionism of the silent version or to the imaginative use of sound in the second film, Die 1000 Augen des Dr Mabuse has always been viewed as the somewhat myopic member of the trio.

From the perspective of film sound, it is this second Mabuse film that invites renewed attention. As with $M$, Lang was keen to explore the creative potential of a sync soundtrack in different ways, particularly in the split sound/picture editing techniques that can equally juxtapose or connect plot lines, characters or locations. Throughout Testament, Lang uses this editing technique to allow the audience to develop linkages via the interplay of sound and image narrative; these connections help the audience to understand narrative nuances of the storyline before they became understood by the protagonists on the screen - chiefly, police investigator Lohmann, who is trying to solve a criminal puzzle of intricate complexity.

Lang consistently uses sound effects which shift in terms of their meaning or their relationship to the image. In one instance Inspector Lohmann is seen looking at his watch, trying to ascertain whether it is still functioning correctly - however, the ticking that can then be heard turns out not to emanate from the timepiece itself, but from a bomb, which becomes apparent in the shot change to the next scene in an entirely different location, unconnected to Lohmann.

Lang explores the narrative potential sync sound brings to his film, incorporating into Das Testament des Dr Mabuse ideas that had come to him from real-life experiences. Lang apparently encountered a device that allowed a gramophone to become linked to an alarm clock, thus making "actually" accurately cued playing of a gramophone sound recording possible. The director used a variation of this idea to create a trick alibi in Testament - the voice of one of the characters is heard at certain times during the film out of vision (suggesting this particular character's physical presence in the vicinity of the sound of his voice) when in fact he was present at a different location.

Elsewhere, Lang plays with the novelty of sync dialogue in his depiction of a conversation between two gangsters - a cozy kitchen scene of criminal domesticity. One gangster is assessing the loot from a spectacular diamond heist at the kitchen table, while his accomplice noisily 
struggles with cooking utensils and reticent sausages in the background. Both are musing about the motivation of the criminal mastermind for whom they work. This scene is suddenly interpolated by another dialogue exchange in a different location, between two other gangsters, before cutting back to the original kitchen pair. These transitions appear out of step at first, like a non sequitur, but the content of the two separate conversations is linked, complimenting one another and making sense when viewed by the audience as part of the whole narrative. Through this editing technique, Lang uses dialogue to create a mise-en-scene greater than its constituent parts, thus enabling his audience privileged insights into the narrative, whilst the film's characters are still struggling to make sense of on-screen events. As we leave the gangsters in the kitchen, they decide that it is safer to remain in ignorance of their master rather than to ask too many questions or even to break out of their criminal existence. This assertion is immediately juxtaposed by the cut to next scene, in which another character is grappling with his conscience, contemplating leaving this same criminal circle with which he has become embroiled. This editing style provides another moment of counterpoint and contrast, repeated consistently in Lang's virtuoso approach to the images and sounds of Das Testament des Dr Mabuse.

Lang also demonstrates an imaginative use of sound effects and voice. In one scene, Lohmann comes face to face with a man who is a former colleague of the Inspector, and who is now holed up in a mental asylum. As the policeman tries to glean more information from the patient, the man is able only to respond with a dissonant rendition of a popular ditty, though (as the Inspector turns away to leave) this becomes interspersed with more coherent, but seemingly out of context, fragments from a remembered telephone conversation. As the man resumes his tuneless song in an eerily feeble voice, Inspector Lohmann realises the potential of sound to prompt associations. The Inspector attempts to trigger further information from the subject using a chiming effect from his pocket watch to simulate the sound effect of a telephone ringing.

Dr Hans Erdmann, who had previously composed the score for Murnau's (silent) Nosferatu, wrote the music for Das Testament des Dr Mabuse. However, for a considerable part of the film, very little music is present, reserved mostly for apparitions of the ghost of Dr Mabuse. Whether the music, which can be heard in the background of a café scene, is part of the diegetic space remains fairly ambivalent. For most of the film sound effects replace the need for score, particularly notable near the end of the film, with the climactic destruction of the gas works and the subsequent car chase scene, which (as with other visual effects in the film) displayed a technical brilliance and groundbreaking innovation. It is not until the car chase is well under way, that a non-diegetic musical element is added to the soundtrack. [...]

\section{Lotte Eisner wrote:}

At the end of the film, the sound swells into a broad orchestration blending with the movements and lighting effects. To the crackling 
of the flames coming from the burning gasworks are added the wailing of sirens, the clanging of fire engines, the rumbling of falling chimneys, the puffing of a locomotive, and the backfiring of motorcycles. Amidst all this din spotlights scanning the bushes track down the villain, and headlights light up the vast thicket pierced by police whistles. A motorcar roars off. And the frantic chase begins. (Eisner 1965:324)

As an extra menu feature available on each DVD, the American film scholar David Kalat provides an insightful (albeit rapid) commentary discussing Lang's Dr Mabuse cycle in terms of its wide-ranging referential and contextual aspects. Drawing on his many years of dedicated research into Mabuse, Kalat is able to identify particular aspects of note, and compare between this and previous, less complete, versions. However, under the proviso that it is nearly impossible confidently to pronounce any restored version as truly 100\% 'authentic' (measured by the standard of the original, as premiered, at any rate), Kalat wisely acknowledges the perils of any archival restoration that has to draw on a myriad of sources. ${ }^{2}$

Kalat's commentary also discusses Lang's Mabuse in relation to its literary source material. The character of Dr Mabuse was based on the successful 1920 novel of the same title by Norbert Jacques. Lang's interpretation of the text was adapted for the screen by Thea von Harbou, whom Lang had met while both were working on Das Indische Grabmal (The Indian Tomb, 1922). Lang had been preparing to direct this epic film, but its producer Joe May decided at the last minute to direct the film himself on account of Lang's perceived lack of experience in big-budget productions. As a consequence, Lang and von Harbou severed their links with May's film company and joined Erich Pommer's thriving Decla-Bioscop, which was about to become incorporated under the umbrella of the Ufa studios.

Striking similarities as well as differences emerge when comparing Lang's first two sound films. On a visual level, it is notable that the title shot for Das Testament des Dr Mabuse explicitly depicts the first letter of the name Mabuse as highlighted, almost as a solo letter ' $M$ ', a visual detail that would not have been entirely lost on its original audience.

But where Mabuse resonates in harmony with its predecessor $M$ in terms of its visual style or its approach to dialogue editing, interesting contrasts between the two films' use of sound may also be observed. The soundtrack of $M$ called the audience immediately to attention with the sound of a singular gong:

A thundering gong rings out and reverberates over a dark screen for a full ten seconds. Lang, the consummate modernist, begins his film with the medium's bare essentials: a black canvas and a single, resonating sound. This sparseness of means introduces a highly controlled, richly self-reflexive and fully artificial universe in which nothing is left to chance $(. .$.
2. Not only in relation to differing prints located in storage. Kalat relates that many shot angles of the same scene were under consideration for such an archival restoration project, actually derive from original camera negatives, shot from different angles on location at the time, with the intention of generating a greater variety of material for the purpose of international distribution. 
3. 'Wait, wait, just a little while, until the bogey man comes for you ...'
Having secured the audience's attention through the use of the gong, a single girl's voice is then heard over the black screen, chanting a slightly macabre counting rhyme: 'Warte, Warte, nur ein Weilchen - dann kommt der schwarze Mann zu dir...' This was a variation of a well-known German song of the era which told of the misdeeds of a notorious serial killer - a reference that would have struck a familiar chord in the audience of that time. The image then fades up from black to a courtyard in which a group of children is at play. Into the rhythmic pattern of the counting rhyme a female voice abruptly interjects in counterpoint, commanding the children to stop singing 'that damned song'. This opening dialogue invites dual interpretations from the perspective of the viewer: to the children embroiled in their playtime, the rhyme is an innocent (albeit slightly ghoulish) device to count out individual members of their game. To the passing woman climbing the stairs of the tenement block, the rhyme is a source of considerable irritation, expressing at once a different understanding that puts the adult's anxiety into a darker context. The woman is worried, aware that a serial killer preying on young children has been terrorising the city. She is not necessarily worried about these particular children in the courtyard, but apparently in a nervous state of mind on account of a perceived, though unseen, threat. A second female character tries to reassure her with the words that 'as long as we can hear them singing, we at least still know that they are safe'. That second woman transpires to be Frau Beckmann, who at this stage in the film does not realise that her own daughter is to be the mysterious killer's next victim.

Subsequently, we see the increasingly anxious mother waiting in vain for her little daughter's return from school. The parent's desperate calling out of the missing girl's name 'Elsie' becomes detached from the corporeal presence of the mother and is laid over shots of potential playgrounds of the child: an empty laundry attic, the unoccupied chair of the girl at the neatly laid table, and finally Elsie's abandoned toys, her balloon trapped miserably in the telegraph wires; a visual symbol that then merges with a newspaper vendor's voice announcing another murder in the city.

Without wanting to digress too much from this discussion of Dr Mabuse, it is the richly layered detail in terms of meaning and out of vision/in vision sound that has earned Lang such credit for his creative use of audio elements in his first encounter with them through $M$. As will be discussed, Lang continued to develop these sound techniques in his next film, adding further innovative devices.

In the opening of Das Testament des Dr Mabuse, Lang abandons the meticulously controlled, subtle sound detail of $M$ and instead seeks to overload the screen with a cacophony of machine sounds. After the titlecard sequence we can see a man hiding out in a noisy factory environment, trying to escape the notice of two other characters. All dialogue content in this scene is obliterated by the din of the setting (which we later come to learn is being caused by a large printing press), and the two men, on spotting the concealed intruder, are forced to communicate through gestures and grimaces to decide on their next course of action. As the pair exit from the room, the ineffectively concealed man emerges from his 
hiding place, visibly agitated and trying to conjure up a solution to his predicament.

Siegfried Kracauer, although fairly dismissive of Testament as more or less sensationalist trash inferior to Lang's previous film $M$, nonetheless acknowledged 'several brilliant episodes which testify to Lang's talent' - through which the film critic and theorist perceived Lang's use of sound as a metaphor for oppression:

The first is the opening sequence. It shows a man cautiously moving about in an abandoned workshop that seems to be shaken by a perpetual, roaring drone. His apparent fear and this nerve-racking noise are bound to torment an audience [...] Life under a terror regime could not be rendered more impressively, for throughout the sequence the imminence of doom is sensed and no one knows when and where the axe will fall.

(Kracauer 1947:249)

Notwithstanding the fact that Kracauer was writing via his particular prism of psychological interpretation, the opening scene certainly does have an oppressive and threatening feel through its use of ambient noise. It is a curious fact that the actual machines causing this din remain unseen. Unlike film extras, which tend to be seen but rarely heard, the machinery behind the din exists only on a sonic level.

In a subsequent scene an assassination is carried out against the backdrop of a traffic junction. A number of cars, stationary in busy city traffic, are patiently waiting for a busy cross road to become passable. The assassins instigate a great noise by continually sounding their car horn. The other motorists (including the unsuspecting victim) join in enthusiastically and thus, the din of car horns obliterates all other city noise. As in the opening scene, a blanket of sound is thrown over the action, rendering foreground sounds inaudible - most crucially the noise of the pistol as the fatal shots are fired. Incidentally, the car horn as a sound effect had been explored as a solo feature to great effect in the opening scenes of $M$, when Lang used a car horn to draw attention to Elsie Beckmann as she comes out of school, at once throwing an audio spot-light onto the little girl, as well as emphasising her vulnerability and the danger which may threaten her.

Fritz Lang's career witnessed some spectacular highs as well as lows. As mentioned above, of the three Lang interpretations that drew on Jacques' original source material, the last film (Die 1000 Augen des Dr Mabuse) met with only lukewarm response by critics as well as audiences in 1960. This reception stood in total contrast to the original reaction generated by Dr Mabuse - Der Spieler in 1922. Perhaps wishing to draw on this earlier success, Lang was keen to develop the material further as Das Testament des Dr Mabuse a decade later, in tandem with Norbert Jacques who was also working on another book version of the story. However, the political scene in Germany had changed to such a drastic degree in the interim, that the film had barely opened in early 1933 when it was abruptly forbidden by 
4. In Verena Boy's book on the sound film aesthetic of Fritz Lang, the alleged meeting between Goebbels and Lang is called into question: missing passport stamps along with other evidence suggest that neither the fateful encounter, nor Lang's immediate departure from Germany after leaving the Reichspropaganda Minister's office occurred in the manner in which Lang had embellished events in subsequent interviews. In Boy's opinion, the director blended actual events (censorship and withdrawal of the film) with an apocryphal account of this meeting with Goebbels (Boy 2009). the Nazi authorities. The main reason for its withdrawal from distribution was apparently that the authorities viewed the subject matter with suspicion, particularly the concept that one deviant individual could influence the minds of others, luring them to committing violent acts.

In subsequent years, Lang apparently revelled in expanding the antifascist message with which he supposedly imbued Das Testament des Dr Mabuse, though this notion might be viewed with some scepticism. Lang certainly did become involved in anti-fascist circles subsequent to having established himself in Hollywood as a director in the late 1930s - but at the time of filming Testament in 1932, Lang was probably more interested in realising his creative ambitions, rather than in encrypting any veiled political message. However, in one scene when Inspector Lohmann appears to dispute Dr Mabuse's legacy when faced with his mortal remains, it is the director of the mental institution (who had devoted years to studying the mind of the late criminal genius) who comes eerily close to resembling Adolf Hitler in a monologue accompanied by gestures and grimaces reminiscent of the Fübrer. Nonetheless, as this appears unsupported elsewhere, this notion may be considered a fanciful reflection by the author of this particular review. In light of the fact that Lang had a tendency to re-visit and embellish events from his own life in later years, his own account of a meeting to discuss Das Testament des Dr Mabuse with Reichspropaganda Minister Goebbels himself might be taken with a pinch of salt. ${ }^{4}$

That aspect aside, it would be fair to surmise that Goebbels recognised Lang as a filmmaker of great talent who could make potentially useful contributions to the filmic output of fascist Germany. Goebbels' main objection to Das Testament des Dr Mabuse was that he saw it in a similar light to $M$, as somewhat ideologically misguided - however, Lang did not wait to be ideologically 'retuned' and decided to vote with his feet, swiftly departing from Germany in 1933.

\section{SOURCES}

Boy, V. (2009), Exemplarische Analysen Zur Tondramaturgie Bei Fritz Lang - Vom Stummfilm Zum Tonfilm, Saarbrücken: VDM Verlag.

Lang, F. (dir.) (1922), Dr Mabuse-Der Spieler. I Der Große Spieler. Ein Bild der Zeit. Germany: Decla-Bioscop / Ufa.

Lang, F. (dir) (1922), Dr Mabuse - Der Spieler. II Inferno. Ein Spiel von Menschen unserer Zeit. Germany: Decla-Bioscop / Ufa.

Lang, F. (dir) (1931), M-Eine Stadt Such Einen Mörder. Germany: Nero-Film AG.

Lang, F. (dir) (1933), Das Testament Des Dr Mabuse. Germany.*

Lang, F. (dir) (1960), Die 1000 Augen des Dr Mabuse. Germany: CCC-Filmkunst GmbH.

Eisenstein, S. (1949), Film Form, New York: Harcourt, Brace and Company.

Eisner, L. [1965] (2008), The Haunted Screen, Berkeley and Los Angeles: University of California Press. 
Kaes, A. (1999), $M$, London: British Film Institute.

Kracauer, S. [1947] (2004), From Caligari To Hitler: A Psychological History of the German Film, New Jersey: Princeton University Press.

*(should have been Nero-Film AG, but film was not really distributed in Germany until 1951).

\section{CONTRIBUTOR DETAILS}

Maike Helmers joined the Media School at Bournemouth University in 1997 where she is now Senior Lecturer in Sound Design and Editing. Her $\mathrm{PhD} / \mathrm{MPhil}$ research specialises in early German sound film. Prior to this, she worked as an editor at the BBC, where she was involved in a number of award-winning programmes. She is a Fellow of the Higher Education Academy and of the Royal Society of Arts.

E-mail: mhelmers@bournemouth.ac.uk 